"An exploratory study on the impact of social media of selected commercial banks in the Eastern Cape Province, South Africa"

\begin{tabular}{ll} 
AUTHORS & $\begin{array}{l}\text { Khulekani Yakobi } \\
\text { Bethuel Sibongiseni Ngcamu id https://orcid.org/0000-0002-1507-7583 }\end{array}$ \\
\hline KRTICLE INFO & $\begin{array}{l}\text { Khulekani Yakobi and Bethuel Sibongiseni Ngcamu (2016). An exploratory study } \\
\text { on the impact of social media of selected commercial banks in the Eastern Cape } \\
\text { Province, South Africa. Banks and Bank Systems, 11(2), } 95-102 . \\
\text { doi:10.21511/bbs.11(2).2016.09 }\end{array}$ \\
\hline DOI & http://dx.doi.org/10.21511/bbs.11(2).2016.09 \\
\hline RELEASED ON & Saturday, 02 July 2016 \\
\hline JOURNAL & "Banks and Bank Systems" \\
\hline FOUNDER & LLC "Consulting Publishing Company "Business Perspectives"
\end{tabular}

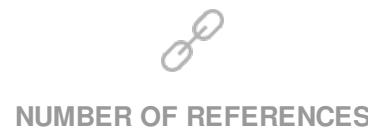

0
NUMBER OF FIGURES

0
NUMBER OF TABLES

0

(C) The author(s) 2022. This publication is an open access article. 


\title{
An exploratory study on the impact of social media of selected commercial banks in the Eastern Cape Province, South Africa
}

\begin{abstract}
The emergence of social media in financially high-risk institutions has had a negative impact on employees' perceptions towards utilization of social media for team collaboration and communication. This study investigates social media impact in commercial banks and explores the contribution it has brought among teams, thus, ascertaining collaboration and effective communication within the banking industry. It adopted a quantitative research method whereby 194 questionnaires were distributed and 102 completed, thereby generating a response rate of 53\%. The study findings revealed $60 \%$ of the research participants who agreed, $14 \%$ undecided, and $27 \%$ disagreed that social media present an opportunity for people to commit fraud and attracts hackers. This study will contribute to the body of knowledge in South Africa as there is a limited number of published studies on the impact of social media in financial institutions.
\end{abstract}

Keywords: Banking industry, business model, collaborations, effective communication, financially high-risk institutions. JEL Classification:

\section{Introduction}

In this century of information technology, social media have increased challenges and opportunities in commercial banks in South Africa. The increased access of the Internet and popularity of networking via virtual platforms of social media has become an integral part of the South African landscape (Gardner, 2011; Olorunnisola, 2013). A plethora of researchers (Blanchard, 2011; Hyde-Clarke, 2011; Nabyla, 2014; and Qualman, 2010) advanced that the evolution of social media revolves around the concept of strategy. This study intends to respond to the above perspectives presented by different authors through positing the deeper understanding of social media, and exploring the importance of social media in the financial institutions. The primary purpose of this study is to investigate the degree of impact made by social media in the commercial banks and contributions it embeds to teams' collaboration, and communication. The number of studies (Cran, 2015; Gilbert, 2016; Treverton, 2016) on the impactsof social media have shown that social media have drastically affected team collaboration, communication and productivity in the commercial banks. According to Katona and Sarvary (2014), social media nowadays have become the prerequisite to create, disseminate, share and exchange information; it is the way in which people interact through ideas in virtual communities or organizations. There is a limited knowledge regarding the use of social media in the commercial banks, and social media adoption by banks and financial institutions is still at a nascent stage (Miranda, Chamorro, Rubio and Morgado, 2013). The primary objectives of this study include: to investigate the impact of social media in

(C) Khulekani Yakobi, Bethuel Sibongiseni Ngcamu, 2016.

Khulekani Yakobi, Master of Business Administration, Financial Economics, Walter Sisulu University, South Africa.

Bethuel Sibongiseni Ngcamu, Doctor of Public Management, Cape Peninsula University of Technology, South Africa. commercial banks; explore contribution it has brought and as certain the level of collaboration, and effective communication within banking industry.

The next section provides conceptual framework, theoretical background, and reviews literature on social media followed by research methodology, results, analysis and discussions and recommendations emanating from the research findings of this study. The study also presents limitations of the study and recommendations for future studies.

\section{Conceptual framework}

The term "social media" has various definitions based on its nature of application, but, for the purpose of this study, the term refers to commercial banks employees' perceptions towards utilization, communication and collaboration. Fuchs (2013) views social media as a medium to engage with the different forms of sociality on the Internet in the context of society. Faller and Schmit (2013) consider social media as a system of discovery, distribution, consumption and conversation surrounding the media, while a plethora of researchers (Brunty and Helenek, 2014; Dahl, 2014; and Gould, 2015) aver that "social media" are web-based tools for interaction that, in addition to conversation, allow users to share contents such as photos, videos, and links to resources. This study acknowledges the different perspectives advanced by above authors which contribute to describe social media. However, this study intends to establish interpretation of use of social media in financial institutions spectrum. As there is a paucity of literature which was identified by this study and the limited evidence which clearly describe social media in the context of commercial banks, this study, in identification of that gap in the literature, will attempt and seek to conceptualize the use and utilization of social media in the financial institutions. 


\section{Theoretical background}

The objective of this study is to establish a task technology fit model in financial institutions by exploring effective communication in commercial banks, collaboration, and utilization. This study intends to provide a theory-grounded reinterpretation of social media impact in South African banks since they are perceived to be reluctant institutions to easily adapt to this phenomenon. D'Ambra, Wilson and Akter (2013) posit that task technology fit (TTF) is an established theoretical framework in information systems research that enables the investigation of issues of fit of technology to tasks, as well as performance. According to Gebauer and Tang (2008), the theory of task technology fit maintains that a match between business tasks and information technology is important to explain and predict the success of information systems. Shang, Chen and Chen (2007) contend that the TTF model suggests that the impact of information technology characteristics on user evaluations will depend upon how important the characteristics are, which determined by users' task needs. This study is grounded on the above theory of TTF as it investigates and tests the utilization of relevant technologies in the financial institutions to improve their performance, which include several factors: communication, collaboration and utilization.

\section{Literature review}

3.1. International perspective on social media. At the international scope, the literature evaluated was based on the impact of social media, and key factors that concern team collaborations, communication, and productivity. Among aspects addressed these are the changes in people's communication, social media has rapidly become part of how people communicate...this is especially true as broadband internet access has become ubiquitous throughout the world (Scott and Jacka, 2011). Munar, Gyimóthy and Cai (2013) confirm that the widespread use of social media sites raises issues related to social influence in the global market. Hacioglu and Dincer (2013) contend that data improvements and Information Communication Technologies (ICT) developments, especially on the Internet phenomena, affected financial markets directly and inevitably. Gonzalez (2014) indicates that there are many benefits to companies using digital and online technology, but there are many risks as well. This study investigates whether collaborative teams in financial institutions depend on the use of social media to collaborate on tasks and enhance suitable communication. Turban, Strauss and Lai (2015) posit that collaboration helps with solving business problems and uncovering new opportunities, especially with the help of social media tools. According to Steven (2012), social media can be seen as a new way of combining technologies, com- munity users' activities and different users' communities and groups. The employees at the banks are directly affected by these drastic changes in communications caused by social media. This study is in alignment with the above advanced perspectives from different authors and further investigates whether social media are becoming unavoidable to many organizations to engage in the online activities since many are often competing within a global market.

\subsection{South African perspectives on social media.}

South Africa still remains a compatible country, but less so regarding the emergence of social media in organizational perspective, increasing the quality and quantity of skilled labor can, therefore, generate additional 1.5 million jobs relative to the baseline and raise potential growth to 7 per cent (South African Reserve Bank, 2013). Cross (2013) indicates that social media take traditional forms of media to a whole new level. Therefore, innovation in communication and collaboration is through adaption to social media. Some studies have found that social media use in South Africa continues to grow, with Facebook leading the trend, growing from 6.8 million users in 2013 to 9.4 million users in 2014 (Mushwana and Bezuidenhout, 2014; Adeyinka, 2014). Hugo (2015) points out that only the high level of public in South Africa are using the Facebook to engage in discussions of a political nature, and using the platforms to connect to each other and share political information in new ways. Camillo (2015) suggests that, when measuring the influence of social media the business performance, there are two main aspects to consider: impacts and return on investment (ROI). Social media in its essence have positive and negative implications on change. Numerous authors (Razmerita, Philips-Wren and Jain, 2015; Just, 2015) indicate major changes brought by Web 2.0, that social media technologies are seeping into organizations, thus, transforming business processes and raising performance. This study investigates whether there are problems in the utilization of social media since South Africans do not use social media for business purposes, but to share political information. This above-mentioned perspective indicates that use of social media in South Africa is for political information-sharing purposes, while the current study explored whether South African organizations adopt it for the same purpose or not. The study investigated the notion that social media, in financial institutions, can add innovation and improve performance, because, through collaboration, teams will emerge. The above perspectives are linked to this study, because it investigates whether these two financial institutions should adapt to social media and administer changes which social media bring so that they could stay on par with innovation and competition. 


\section{Research methodology}

This present study has adopted quantitative research method which was the main approach guideng the study. According to Creswell (2013), quantitative methods involve the process of collecting, analyzing, interpreting, and writing the results of a study. Therefore, a quantitative research design was relevant for this study as it explored experiences, operations, perspectives, perceptions and feelings of bank employees on the use of social media among their team collaborations. This was an empirical study which was conducted by means of a survey questionnaire which provided for the collection of large amounts of data. Structured questionnaires were distributed respectively to two commercial banks' (ABSA and Standard Bank) employees located in the Eastern Cape Province. The structured questionnaires were distributed to the population size of 194 employees with 102 returned and completed successfully, thereby generating a response rate of $53 \%$. The non-respondents in this study were identified to be 92 unreturned questionnaires from two commercial banks which have been considered not to be bias, but signified inequality of gender composition in these respective commercial banks. The study targeted both males and females in the banks, and survey respondents were not selected in the first instance to be a single gender, it has shown high response rate to be female which disregard their male counterpart presence.

4.1. Participants. This study targeted the population size of 194 employees in two major (ABSA and Standard Bank) South African banks whereby a sample size of 102 employees were sampled. The selection criteria of research subjects were for them to be bank employees and be 18 years and older. The sampled target population included middle to lower management levels, which were performing the core roles and duties of business administration. Such core roles could consist of managing and controlling information circulation and retrieving fundamental elements for the banks' life or existence. This study targeted tellers, sales consultants, credit analysts, credit managers and branch Managers with the purpose of exploring the empirical influence and impact of social media.

4.2. Instrument. To allow participation of bank employees from different branches, a structured questionnaire was self-developed and self-administered to ensure response of participants. A Likert scale type of questionnaire was relevant for this study to examine different dimensions and relationships between employees' variables. Numerous authors (Azzara, 2010; Boone and Boone, 2012; Phakiti, 2014; and Remenyi, 2012) contributed to the insight and development of this questionnaire. The research instrument consisted of 50 items, with the levels of measurement at nominal or ordinal levels. The questionnaire was divided into 6 sections which measured various themes which are: biographical data, understanding of social media, social media optimism, social media influence on human interactions, challenges of social media in banks, and perceptions in business etiquette.

\section{Data analysis}

The data collected from the responses were analyzed with SPSS version 23.0.

5.1. Reliability: Cronbach's coefficient Alpha. According to Golafshani (2003), the extent to which results are consistent over time and an accurate representation of the total population under study is referred to as reliability; if the results of a study can be reproduced under a similar methodology, then, the research instrument is considered to be reliable. The overall reliability score $(0.929)$ of this study exceeds the recommended Cronbach's Alpha value of 0.700. This indicates a high degree of acceptable, consistent scoring for the various sections of the research.

5.2. Ethical considerations. Research ethics involves requirements on daily work, the protection of dignity of subjects and the publication of the information in research (Fouka \& Mantzorou, 2011). A permission letter was obtained from these two major financial banks in the Eastern Cape Province in order to conduct this study. The study further ensured full confidentiality of information given and protected the identities of bank employees who participated. Furthermore, it ensured that human rights are not violated and commercial banks' principles, rules and regulations were adhered at all costs.

\section{Research findings}

6.1. Pearson Chi-square test. The study findings revealed that almost all sub-dimensions of the study have a Pearson Chi-square test of 0.000 which determines a significant relationship between variables of the study; this implies that most respondents agreed with the statements of the study. The Chi-square test only depicted two variables of the study (social media often delays productivity at 0.26 ) and "it brings difficulties to manage these internet-based relationship" thus indicating that

6.2. Hypothesis testing. The study findings revealed a positive and significant relationship between social networking as a great contributor to business productivity and that social media, as a medium, enhance communication effectiveness at $0.448^{* * *}$. This indicates that employees who are actively involved in social media are likely to contribute positively on productivity of these organizations. Furthermore, finding 
showed that the more employees communicate increase productivity, thereby increasing their through social media, the more likely they are to performance.

Table 1. Gender distribution by age

\begin{tabular}{|c|c|c|c|c|c|}
\hline & & & \multicolumn{2}{|c|}{ Gender } & \multirow[t]{2}{*}{ Total } \\
\hline & & & Male & Female & \\
\hline \multirow{12}{*}{ Age (years) } & \multirow{4}{*}{18 to 34} & Count & 21 & 46 & 67 \\
\hline & & $\%$ within age (years) & $31.3 \%$ & $68.7 \%$ & $100.0 \%$ \\
\hline & & $\%$ within gender & $80.8 \%$ & $60.5 \%$ & $65.7 \%$ \\
\hline & & $\%$ of total & $20.6 \%$ & $45.1 \%$ & $65.7 \%$ \\
\hline & \multirow{4}{*}{35 to 54} & Count & 5 & 29 & 34 \\
\hline & & $\%$ within age (years) & $14.7 \%$ & $85.3 \%$ & $100.0 \%$ \\
\hline & & $\%$ within gender & $19.2 \%$ & $38.2 \%$ & $33.3 \%$ \\
\hline & & $\%$ of total & $4.9 \%$ & $28.4 \%$ & $33.3 \%$ \\
\hline & \multirow{4}{*}{65 and above } & Count & 0 & 1 & 1 \\
\hline & & $\%$ within age (years) & $0.0 \%$ & $100.0 \%$ & $100.0 \%$ \\
\hline & & $\%$ within gender & $0.0 \%$ & $1.3 \%$ & $1.0 \%$ \\
\hline & & $\%$ of total & $0.0 \%$ & $1.0 \%$ & $1.0 \%$ \\
\hline \multirow{4}{*}{\multicolumn{2}{|c|}{ Total }} & Count & 26 & 76 & $102 \%$ \\
\hline & & $\%$ within age (years) & $25.5 \%$ & $74.5 \%$ & $100.0 \%$ \\
\hline & & $\%$ within gender & $100.0 \%$ & $100.0 \%$ & $100.0 \%$ \\
\hline & & $\%$ of total & $25.5 \%$ & $74.5 \%$ & $100.0 \%$ \\
\hline
\end{tabular}

Table 1 demonstrates a correlation gender distribution which was illustrated by different significant representations, whereby females have shown a high percentage of representation than their male counterparts.

Table 2. Understanding of social media

\begin{tabular}{|l|c|c|c|}
\hline \multicolumn{1}{|c|}{ Understanding of social media } & Disagree & $\begin{array}{c}\text { Unde- } \\
\text { cided }\end{array}$ & Agree \\
\hline $\begin{array}{l}\text { Social media as a medium that } \\
\text { enhances communication effective- } \\
\text { ness }\end{array}$ & $10.8 \%$ & $10.8 \%$ & $78.4 \%$ \\
\hline $\begin{array}{l}\text { Social media as a medium of collabo- } \\
\text { rating teams to practical collaboration }\end{array}$ & $7.8 \%$ & $15.7 \%$ & $76.5 \%$ \\
\hline $\begin{array}{l}\text { Banks only staying competitive } \\
\text { through the utilization of social media }\end{array}$ & $16.7 \%$ & $18.6 \%$ & $64.7 \%$ \\
\hline $\begin{array}{l}\text { Driving banks' business processes to } \\
\text { change }\end{array}$ & $9.8 \%$ & $24.5 \%$ & $65.7 \%$ \\
\hline Attracting potential hackers & $14.7 \%$ & $17.6 \%$ & $67.6 \%$ \\
\hline $\begin{array}{l}\text { As an opportunity for people to } \\
\text { commit fraud }\end{array}$ & $26.5 \%$ & $13.7 \%$ & $59.8 \%$ \\
\hline $\begin{array}{l}\text { Social media as a learning content to } \\
\text { understand cultural differences }\end{array}$ & $11.8 \%$ & $22.5 \%$ & $65.7 \%$ \\
\hline $\begin{array}{l}\text { Social networking as a great contribu- } \\
\text { tor to business productivity }\end{array}$ & $7.8 \%$ & $13.7 \%$ & $78.4 \%$ \\
\hline $\begin{array}{l}\text { Social media as a way of improving } \\
\text { performance }\end{array}$ & $19.6 \%$ & $14.7 \%$ & $65.7 \%$ \\
\hline $\begin{array}{l}\text { Social media as a way to promote } \\
\text { innovation }\end{array}$ & $7.8 \%$ & $14.7 \%$ & $77.5 \%$ \\
\hline
\end{tabular}

Table 2 illustrates the understanding of social media on bank employees, which has relatively shown positive understanding in its contribution, but respondents also revealed that social media attract potential hackers and provide an opportunity for people to commit fraud.

Table 3. Social media optimism

\begin{tabular}{|c|c|c|c|}
\hline \multicolumn{1}{|c|}{ Social media optimism } & Disagree & Undecided & Agree \\
\hline $\begin{array}{l}\text { Has become a suitable communication } \\
\text { strategy in all business operations }\end{array}$ & $15.7 \%$ & $22.5 \%$ & $61.8 \%$ \\
\hline
\end{tabular}

\begin{tabular}{|l|c|c|c|}
\hline $\begin{array}{l}\text { Has an excellent contribution towards } \\
\text { team work discussions }\end{array}$ & $17.6 \%$ & $20.6 \%$ & $61.8 \%$ \\
\hline $\begin{array}{l}\text { Is an essential tool for professional } \\
\text { business meetings }\end{array}$ & $23.5 \%$ & $27.5 \%$ & $49.0 \%$ \\
\hline $\begin{array}{l}\text { Is a prerequisite for developing and } \\
\text { building new ideas }\end{array}$ & $23.5 \%$ & $21.6 \%$ & $54.9 \%$ \\
\hline $\begin{array}{l}\text { Ascertains good productivity in any } \\
\text { individual assigned tasks }\end{array}$ & $15.7 \%$ & $28.4 \%$ & $55.9 \%$ \\
\hline $\begin{array}{l}\text { Ensures the total measure of my } \\
\text { competence }\end{array}$ & $12.7 \%$ & $32.4 \%$ & $54.9 \%$ \\
\hline Has improved my literacy skills & $21.6 \%$ & $19.6 \%$ & $58.8 \%$ \\
\hline $\begin{array}{l}\text { Has trained many employees to handle } \\
\text { diversity }\end{array}$ & $18.6 \%$ & $20.6 \%$ & $60.8 \%$ \\
\hline $\begin{array}{l}\text { Continues to help employees to stay } \\
\text { updated at all times in all spheres }\end{array}$ & $2.9 \%$ & $24.5 \%$ & $72.5 \%$ \\
\hline
\end{tabular}

Table 3 shows the level of employee's optimism towards social media in financial institutions. Respondents confirmed the usefulness of social media in their production, but lack trust for professional considerations.

Table 4. Social media influence on human interactions

\begin{tabular}{|l|c|c|c|}
\hline \multicolumn{1}{|c|}{$\begin{array}{c}\text { Social media influence on human } \\
\text { interactions }\end{array}$} & Disagree & Undecided & Agree \\
\hline Changed how work used to flow & $23.5 \%$ & $22.5 \%$ & $53.9 \%$ \\
\hline $\begin{array}{l}\text { Started the openness of emotions on } \\
\text { employees }\end{array}$ & $23.5 \%$ & $27.5 \%$ & $49.0 \%$ \\
\hline $\begin{array}{l}\text { Brought a great cohesiveness among } \\
\text { employees }\end{array}$ & $20.6 \%$ & $22.5 \%$ & $56.9 \%$ \\
\hline $\begin{array}{l}\text { Created online communities that can be } \\
\text { easily managed }\end{array}$ & $14.7 \%$ & $24.5 \%$ & $60.8 \%$ \\
\hline $\begin{array}{l}\text { Improved supervision from management } \\
\text { towards employees }\end{array}$ & $27.5 \%$ & $21.6 \%$ & $51.0 \%$ \\
\hline $\begin{array}{l}\text { Totally transformed channels of commu- } \\
\text { nication }\end{array}$ & $9.8 \%$ & $24.5 \%$ & $65.7 \%$ \\
\hline
\end{tabular}

Table 4 reflects the influence of social media which has been considered unavoidable by respondents, this 
highlights the way in which social media have influence on employees interaction in their facets. Table 4 also revealed that social media obscure the emotions of employees at the banks.

Table 5. Challenges of social media in banks

\begin{tabular}{|l|c|c|c|}
\hline \multicolumn{1}{|c|}{ Challenges of social media in banks } & Disagree & Undecided & Agree \\
\hline $\begin{array}{l}\text { Employees become free in expressing } \\
\text { how they feel through social media } \\
\text { platforms }\end{array}$ & $25.5 \%$ & $13.7 \%$ & $60.8 \%$ \\
\hline $\begin{array}{l}\text { Employees use social media platform to } \\
\text { gossip }\end{array}$ & $30.4 \%$ & $21.6 \%$ & $48.0 \%$ \\
\hline $\begin{array}{l}\text { Communication is greatly distorted by } \\
\text { social media }\end{array}$ & $23.5 \%$ & $28.4 \%$ & $48.0 \%$ \\
\hline $\begin{array}{l}\text { Employees have rights to reveal informa- } \\
\text { tion as the practice of freedom of speech }\end{array}$ & $32.4 \%$ & $15.7 \%$ & $52.0 \%$ \\
\hline $\begin{array}{l}\text { Employees share videos to spread false } \\
\text { statements in the event of conflicts }\end{array}$ & $45.1 \%$ & $22.5 \%$ & $32.4 \%$ \\
\hline $\begin{array}{l}\text { Employees use social media platforms } \\
\text { as an opportunity to establish relation- } \\
\text { ships }\end{array}$ & $25.5 \%$ & $16.7 \%$ & $57.8 \%$ \\
\hline
\end{tabular}

Table 5 reveals challenges imposed by social media as a contemporary evolving strategy of doing business. The respondents felt that it is complex to deal with advent of social media in financial institutions.

Table 6. Perceptions in business etiquette

\begin{tabular}{|l|c|c|c|}
\hline \multicolumn{1}{|c|}{ Challenges of social media in banks } & Disagree & Undecided & Agree \\
\hline $\begin{array}{l}\text { It continues to change how decisions are } \\
\text { made }\end{array}$ & $14.7 \%$ & $28.4 \%$ & $56.9 \%$ \\
\hline It makes employees less innovative & $33.3 \%$ & $21.6 \%$ & $45.1 \%$ \\
\hline It often delays productivity & $35.3 \%$ & $21.6 \%$ & $43.1 \%$ \\
\hline It allows much leisure during production & $20.6 \%$ & $32.4 \%$ & $47.1 \%$ \\
\hline It unveils confidentiality of information & $22.5 \%$ & $24.5 \%$ & $52.9 \%$ \\
\hline It impetus more costs for its use & $25.5 \%$ & $26.5 \%$ & $48.0 \%$ \\
\hline $\begin{array}{l}\text { It brings difficulties to manage these } \\
\text { internet-based services }\end{array}$ & $33.3 \%$ & $30.4 \%$ & $36.3 \%$ \\
\hline $\begin{array}{l}\text { It slightly redefines organizational } \\
\text { capacity to transfer knowledge }\end{array}$ & $20.6 \%$ & $29.4 \%$ & $50.0 \%$ \\
\hline $\begin{array}{l}\text { Its implications intends to dent the image } \\
\text { of the banking industry }\end{array}$ & $34.3 \%$ & $17.6 \%$ & $48.0 \%$ \\
\hline $\begin{array}{l}\text { It continues to compromize the reputation } \\
\text { of the industry }\end{array}$ & $30.4 \%$ & $21.6 \%$ & $48.0 \%$ \\
\hline
\end{tabular}

Table 6 shows how employees have exercised freedom in their environment, expressing how they feel through social media platforms with high representation of $(60.8 \%)$, wherein, social media has also necessitated establishment of new relationships among employees.

\section{Discussions}

The primary objective of this study was to investigate the impact of social media in the two commercial banks in the Eastern Cape Province, Mthatha (O.R. Tambo District). Respondents, in the gender distribution by age, showed disproportionate representation of gender inequality. This is a result shown by female youth (aged 18 to 34) outnumbering male counterparts by a large percentage. This finding is in disagreement with Metcalf and Rolfe (2009) who claim that banks employ a relatively high percentage of people in the 25 to 39 age range and fewer in older age ranges. The high percentage of respondents who revealed that social media is a medium that enhances communication effectiveness is in disagreement with Blanchard (2011) who claims that social media are now bringing about its own evolution, not only in communication. Major findings show that many respondents perceive social media to be attracting potential hackers to banks. It is in agreement with Youngblood (2015) that many of the successful fraud schemes generated through sending of unsolicited e-mails are currently delivered to the targeted individual on social media websites. This finding is also supported by Headworth (2015) that social media with web-based platforms expose banks to numerous forms of computer crimes and business risks.

Participants have shown the highest response that social media continue to help employees to stay updated at all times in all spheres. This finding was in agreement with Jalonen (2014) who states that social media increases the connectivity of people within and across organizational boundaries. Within the dimension of social media's influence in human interaction, a high percentage of agreement was shown by respondents that social media have changed workflow. This finding is congruent to Langer's (2014) concern that social media becomes increasingly prominent in organizations and have affected the way in which we communicate internally and externally. In the context whereby social media have totally transformed channels of communication, many employees indicated large percentage of agreement.

Among the challenges of social media in banks revealed were that social media continue to change how decisions are made, and a high response percentage was shown in this regard to confirm how employees agreed with this statement. This finding was confirmed by Kadam and Ayarekar $(2014$, p. 3) that social media have changed the delivery, structure and availability of information. Negative response showed that social media allow much leisure with regard to production. This finding is in disagreement with Karampelas (2012) who notes that employees in a group keep on encouraging others to be committed in assigned tasks. Regarding perceptions of business etiquette, many employees highly agreed that bank employees become free in expressing how they feel through social media platforms. This finding is in agreement with Kazienko and Chawla (2015) as they claim that today's constant Internet connectivity and mobile devices have drastically changed employee's lifestyles from face-to-face to online conversations. Participants did not totally agree with the perceptions that employees use social media platform to gossip. This sub-dimension is in disagreement with Hugo 
(2015) who found that only the high level individuals in South Africa are using Facebook to engage in discussions of a political nature and use platforms to connect to each other and share political information.

\section{Conclusion}

It may be concluded in this article that the perceptions of bank employees concerning social media impact on their operations were negative. The primary objective of this study endeavored to establish the critical role of social media, the degree of their impact on employees of commercial banks, and examining perceptions of social media value on employees and embedded risks. This study observed that ubiquity of social media has created negative perceptions on its impact in financial institutions. The findings shown in this study which are counter-productive were that social media attract potential hackers and bidding fraud. This has become a problem which will result in excessive loss of financial credibility of two commercial banks (ABSA and Standard Bank). This article reveals that there is no absolute optimism because employees lack trust in social media as they continue to exacerbate unprofessionalism and violate the core values and principles of organizations in these commercial banks. The study also observed that there are many challenges of social media in the commercial banks and which are continuing to enact the negative impact in all the banks' facets. This has immensely disregarded the value of and use of social media by employees in the banks. The study, in addition, showed that social media are denting the image of commercial banks. It observed that social media affect banks communication strategies negatively. This study also concludes that social media platforms create onerous implications of distorting communication in the organizations, because employees utilize them to gossip and spread false statements in the event of conflicts.

\section{Recommendations}

The present paper suggests that commercial banks (ABSA and Standard Bank) should review their re- cruitment strategies and strive to balance the levels of employment on the basis of gender. Failure to review their recruitment and selection strategies will result in the banking industry being regarded as a discriminatory industry on the basis of gender. In order to address these potential threats presented in the understanding of social media, it is vital for branch managers to stay vigilant in advancing policies and core values which should intensely regulate the use of social media. The formulation and development of these policies must be made known to all employees at all levels of management. Management should train and develop their employees on the ethical use of social media among employees', thus, increasing professionalism and productivity. The goals and aims of the training and development should be within the context of building trust among teams in these commercial banks, because building trust will necessitate cohesiveness and productivity through these technologies, that is, social media. Maintaining online communities is crucial to be kept, especially in this digital evolving business world, but the structures of communication have to be well administered through involvement of all stakeholders and people responsible for different levels in management, i.e., branch levels. In order to address these challenges of social media which are faced by commercial banks, it is imperative that commercial banks should realize their strength and capability of managing Internet-based services and, then, capitalize on those strengths.

Limitations of the study and advice for future studies. A single approach of research method created limitations since the quantitative methodology was the only method employed throughout the study. For future studies, researchers should adopt a mixed methods research approach on the use of social media in commercial banks. Therefore, future studies could address the impact of social media at a national level and even beyond that, at an international level.

\section{References}

1. Agbinya, J.I. (2011). Principles of Inductive Near Field Communications for Internet of Things. Denmark: River Publishers.

2. Azzara, C.V. (2010). Questionnaire Design for Research: Beyond Linear Thinking-An Interactive Approach. USA: Tate Publishing.

3. Blanchard, O. (2011). Social Media ROI: Managing and Measuring Social Media Efforts in Your Organization, USA: Pearson Education.

4. Boone, H.N. and Boone, D.A. (2012). Analyzing Likert Data, Journal of Extension, 50 (2), 2, pp. 1-5.

5. Brunty, J. and Helenek, K. (2014). Social Media Investigation for Law Enforcement. New York: Routledge.

6. Camillo, A.A. (2015). Handbook of Research on Global Hospitality and Tourism Management, USA: IGI Global.

7. Choi, N., Huang, K., Palmer, A. \& Horowitz, L. (2014). Web 2.0 Use and Knowledge Transfer: How Social Media Lead to Organizational Innovation, Electronic Journal of Knowledge Management, 12, pp. 176-186.

8. Cran, C. (2015). The Art of Change Leadership: Driving Transformation In a Fast-Paced World. USA: John Wiley \& Sons.

9. Creswell, J.W. (2013). Research Design: Qualitative, Quantitative, and Mixed Methods Approaches. Singapore. SAGE Publications.

10. Cross, M. (2013). Social Media Security: leveraging Social Networking While Mitigating Risk. USA: Newnes. 
11. D’Ambra, J., Wilson, C.S. and Akter, S. (2013). Application of the task-technology fit model to structure and evaluate the adoption of E-books by Academics, Journal of the American Society for Information Science and Technology, 64 (1), pp. 48-64.

12. Dahl, S. (2014). Social Media Marketing: Theories and Applications. Singapore: SAGE.

13. Faller, C. and Schmit, K. (2013). Social Media Shitstorms: Origins, Case Studies and Facts about Social Media Crises and their Consequences for Crisis Management. BoD - Books on Demand.

14. Fouka, G. and Mantzorou, M. (2011). What are the Major Ethical Issues in Conducting Research? Is there a Conflict between the Research Ethics and the Nature of Nursing? Health Science Journal, 5 (1), pp. 3-14.

15. Fuchs, C. (2013). Social Media: A Critical Introduction. Britain: SAGE.

16. Franzosi, R. (2011). Content Analysis: Objective, Systematic, and Quantitative Description of Content, pp. 21-49, July 14.

17. Gardner, J.A. (2011). Innovation and the Future Proof Bank: A Practical Guide to Doing Different Business-asUsual. India: John Wiley \& Sons.

18. Gebauer, J. and Tang, Y. (2008). Applying the theory of task-technology fit to mobile technology: the role of user mobility, International Journal of Mobile Communications, 6 (3), pp. 321-344.

19. Gilbert, S. (2016). Strategic Integration of Social Media into Project Management Practice. USA: IGI Global.

20. Golafshani, N. (2003). Understanding Reliability and Validity in Qualitative Research, The Qualitative Report, 8, pp. 597-607, 4, December.

21. Gonzalez, D. (2014). Managing Online Risk: Apps, Mobile, and Social Media Security. UK: ButterworthHeinemann.

22. Gould, M. (2015). The Social Media Gospel: Sharing the Good News in New Ways. USA: Liturgical Press.

23. Hacioglu, U. and Dincer, H. (2013). Managerial Issues in Finance and Banking: A Strategic Approach to Competitiveness. Switzerland: Springer Science \& Business Media.

24. Headworth, A. (2015). Social Media Recruitment: How to Successfully Integrate Social Media into Recruitment Strategy. India: Kogan Page Publishers.

25. Hugo, A. (2015). Cases on Strategic Social Media Utilization in the Nonprofit Sector. USA: IGI Global.

26. Hyde-Clarke, N. (2011). Communication and Media Ethics: In South Africa. South Africa: Juta and Company Ltd.

27. Jalonen, H. (2014). Social Media and Emotions in Organisational Knowledge Creation, Proceedings of the 2014 Federated Conference on Computer Science and Information Systems, Vol. (2), pp. 1371-1379, Fall.

28. Just, J. (2015). Jihad 2.0: The Impact of Social Media on the Salafist Scene and the Nature of Terrorism. Germany: Anchor Academic Publishing (app_verlag).

29. Kadam, A. and Ayarekar, S. (2014). Impact of Social Media on Entrepreneurship and Entrepreneurial Performance: Special Reference to Small and Medium Scale Enterprises. SIES Journal of Management, 10 (1), March.

30. Karampelas, P. (2012). Technique and Tools for Designing an Online Social Network Platform. USA: Springer Science and Business Media.

31. Katona, Z. and Sarvary, M. (2014). Maersk Line: B2B Social Media - "It's Communication, Not Marketing”, University Of California, Berkeley, 56 (3), Spring.

32. Kazienko, P. and Chawla, N. (2015). Applications of Social Media and Social Network Analysis. USA: Springer.

33. Langer, E. (2014). What's Trending? Social Media and its Effects on Organizational Communication, Journal of Undergraduate Research, 17, pp. 1-14.

34. Metcalf, H. and Rolfe, H. (2009). Employment and Earnings in the Finance Sector: A Gender Analysis. London and Manchester: Equality and Human Rights Commission.

35. Miranda, F.J., Chamorro, A., Rubio, S. and Morgado, V. (2013). Evaluation of Social Networks Sites in the Banking Sector: An Analysis of Top 200 International Banks, Journal of Internet Banking and Commerce, 18 (2), pp. 1-18.

36. Munar, A.M., Gyimóthy, S. and Cai, L. (2013). Tourism Social Media: Transformations in Identity, Community and Culture. USA: Emerald Group Publishing.

37. Mushwana, G. and Bezuidenhout, H. (2014). Social media policy in South Africa, Southern African Journal of Accountability and Auditing Research, Vol. 1 (16), pp. 63-74.

38. Nabyla, D. (2014). Developing Strategic Business Models and Competitive Advantage in the Digital Sector. USA: IGI Global.

39. Olorunnisola, A.A. (2013). New Media Influence on Social and Political Change in Africa: Advances in Human and Social Aspects of Technology. USA: IGI Global.

40. Phakiti, A. (2014). Experimental Research Methods in Language Learning. Amsterdam: Bloomsbury Publishing.

41. Qualman, E. (2010). Socialnomics: How Social Media Transforms the Way We Live and Do Business: Business professional collection. USA: John Wiley and Sons.

42. Razmerita, L., Philips-Wren, G. and Jain, L.C. (2015). Innovations in Knowledge Management: The Impact of Social Media, Semantic Web and Cloud Computing. Australia: Springer.

43. Remenyi, D. (2012). Field Methods for Academic Research: Interviews, Focus Groups and Questionnaires (3 Ed). UK: Academic Conference Limited. 
44. Shang, R.A., Chen, Y.C. and Chen, C.M. (2007). Why people blog? An empirical investigations of the task technology fit model, PACIS 2007 Proceedings, p. 5.

45. Scott, P.R. and Jacka, J.M. (2011). Auditing Social Media: A Governance and Risk Guide. Canada: John Wiley and Sons, Inc., Hoboken, New Jersey.

46. South Africa. (1998). Employment Equity Act. Notice 19370 of 1998, Government Gazette, 400 (1323), pp. 1-54, October 19.

47. South African Reserve Bank. (2013). Achieving Higher Growth and Employment: Policy Options for South Africa, Statistics South Africa- Quarterly Labour Force Survey, pp. 2-34, 01, December, 2015.

48. Steven, W. (2012). Digital Identify and Social Media. USA: IGI Global.

49. Sultana, N., Abdullah, A.M. and Tabassum, A. (2013). Exploring the communication barriers in private commercial banks of Bangladesh, International Journal of Research Studies in Management, 2 (1), pp. 21-32, April.

50. Treverton, G.F. (2016). New Tools for Collaboration. USA: Rowman \& Littlefield.

51. Turban, E., Strauss, J. and Lai, L. (2015). Social Commerce: Marketing, Technology and Management. USA: Springer.

52. Youngblood, J.R. (2015). A Comprehensive Look at Fraud Identification and Prevention. New York: CRC Press. 